\title{
Contraction of Capital Investment in Retail Trade Sub-Sector Companies on the Indonesia Stock Exchange
}

\author{
Andy \\ Postgraduate Management, Pakuan University, Indonesia
}

S. H. Hengky

Bina Darma University, Indonesia

E-mail: hengky_halim@binadarma.ac.id; hengky_halim@yahoo.com.au

Received: May 1, 2021 Accepted: June 2, $2021 \quad$ Published: June 10, 2021

doi:10.5296/ber.v11i3.18734ＵRL: https://doi.org/10.5296/ber.v11i3.18734

\begin{abstract}
This study aims to compare the investment contraction in the retail trade sub-sector on the Indonesia Stock Exchange (IDX). This study examines the effect of profitability as measured by ROE on capital structure as measured by DER in sub-sector companies in IDX during 2016-2020. This type of research uses verification research with explanatory survey method and sample method of a purposive-sampling in which there are 18 samples of retail company sub-sectors. Methods of data analysis using panel data regression with the results: Profitability has a negative and significant effect on capital structure.
\end{abstract}

Keywords: Return on Equity (ROE), Debt to Equity Ratio (DER)

\section{Introduction}

Indonesia was also affecting by the impact on the Covid-19 impact that caused the national economy to experience a recession in the last 22 years after two consecutive quarters of contraction in the Gross Domestic Product (GDP). One of the sectors that has been affecting is the capital market. Uncertainty is so high that it makes the stock market shaken, which causes capital outflows to come out of the domestic stock market. This phenomenon is also experience by all stock exchanges in the world. The Composite Stock Price Index fell to its lowest level in 2020 at the level of 3,997 on March 24, 2020 (Sidik, 2020).

So that, the correction of the Composite Stock Price Index (CSPI) is not so deeper, the 
regulators, tried to reduce it caused by the pandemic. The CSPI fell $5 \%$ in a day, stock buyback policy on going through the General Meeting of Shareholders, prohibiting short selling transactions and other stimulus packages, and leniency in submitting financial reports for issuers. Not only that, positive sentiments regarding the recovery in the domestic economy are slowly recovering in line with the easing of social restrictions and government stimulus policies, on the stock market is slowly rising.

Stock market turmoil is inevitable amidst the uncertainty caused by the Covid-19 pandemic. However, the good news is that during the crisis, it becomes a momentum to increase the number of domestic retail investors. Retail investors act to a cushion or shock breaker out the stock market experiences a crisis. This phenomenon of increasing the number of retail investors also occurs to stock exchanges in Southeast Asian countries (Safitri, 2020; Sidik, 2020)

The government has issued a Work from Home (WFH) policy or work from home to prevent the spread of the Corona virus. Bank Indonesia (BI) stated that retail investors in the capital market are growing rapidly during the pandemic. This is reflected on the number of retail investors which reached 4.16 million, much higher than the number of retail investors amounted to 2.48 million (2019), 1.62 million (2018), and 1.12 million (2017). This means that retail confidence is extraordinary for future capital-market developments (Melani, 2021; Uly, 2020).

Due to the impact on this pandemic, it will affect its profitability and capital structure. In this study (Table 1), capital structure measured in a Debt to Equity Ratio (DER) (Kurniawan, 2021). While, the profitability is measured by Return on Equity (ROE). The optimal capital structure can change from time and can affect the changes. It will affect capital budget decisions. It ultimately will affect the company's stock price (Pennacchi \& Santos, 2021; Situm, 2021).

Table 1. Profitability and Capital Structure of Retail Companies (2016-2020)

\begin{tabular}{|l|l|l|l|l|}
\hline No & Company & Year & ROE (\%) & DER (\%) \\
\hline 1 & ACES & 2016 & 23,16 & 22 \\
\hline & Ace Hardware Indonesia, Tbk & 2017 & 22,24 & 26 \\
\hline & & 2018 & 18,41 & 27 \\
\hline & & 2019 & 21,6 & 22 \\
\hline & & 2020 & 14,5 & 43 \\
\hline 2 & AMRT & 2016 & 10,46 & 268 \\
\hline & Sumber Alfaria Trijaya, Tbk & 2017 & 4,97 & 321 \\
\hline & & 2018 & 7,5 & 287 \\
\hline & & 2019 & 13,2 & 254 \\
\hline & & 2020 & 12,2 & 262 \\
\hline 3 & CSAP & 2016 & 5,29 & 200 \\
\hline & Catur Sentosa Adiprana, Tbk & 2017 & 5,84 & 237 \\
\hline & & 2018 & 3,35 & 210 \\
\hline & & 2019 & 2,78 & 226 \\
\hline & & 2020 & 3,98 & 250 \\
\hline 4 & DAYA & 2016 & $-24,23$ & 100 \\
\hline & Duta Intidaya,Tbk & 2017 & $-3,29$ & 128 \\
\hline & & 2018 & $-0,03$ & 161 \\
\hline
\end{tabular}




\begin{tabular}{|c|c|c|c|c|}
\hline & & 2019 & 0,6 & 338 \\
\hline & & 2020 & $-56,3$ & 460 \\
\hline \multirow[t]{5}{*}{5} & ECII & 2016 & $-1,87$ & 9 \\
\hline & Electronic City, Tbk & 2017 & $-0,57$ & 11 \\
\hline & & 2018 & 0,78 & 11 \\
\hline & & 2019 & 2,01 & 10 \\
\hline & & 2020 & $-2,52$ & 38 \\
\hline \multirow[t]{5}{*}{6} & ERAA & 2016 & 7,68 & 118 \\
\hline & Erajaya Swasembada,Tbk & 2017 & 9,37 & 139 \\
\hline & & 2018 & 14,44 & 171 \\
\hline & & 2019 & 4,55 & 102 \\
\hline & & 2020 & 7,32 & 82 \\
\hline \multirow[t]{5}{*}{7} & GLOB & 2016 & 17,37 & -111 \\
\hline & Global Teleshop, Tbk & 2017 & 2,14 & -109 \\
\hline & & 2018 & 3,1 & -107 \\
\hline & & 2019 & 5,33 & -105 \\
\hline & & 2020 & 0 & -102 \\
\hline \multirow[t]{5}{*}{8} & HERO & 2016 & 2,21 & 37 \\
\hline & Hero Supermarket, Tbk & 2017 & $-3,68$ & 42 \\
\hline & & 2018 & 1,63 & 48 \\
\hline & & 2019 & $-0,227$ & 52 \\
\hline & & 2020 & $-14,3$ & 89 \\
\hline \multirow[t]{5}{*}{9} & KOIN & 2016 & $-0,01$ & 484 \\
\hline & Kokoh Inti Arebama, Tbk & 2017 & $-13,08$ & 567 \\
\hline & & 2018 & $-9,87$ & 758 \\
\hline & & 2019 & 7,4 & 557 \\
\hline & & 2020 & 6,39 & 477 \\
\hline \multirow[t]{5}{*}{10} & LPPF & 2016 & 108,86 & 162 \\
\hline & Matahari Department Store,Tbk & 2017 & 81,92 & 133 \\
\hline & & 2018 & 60,1 & 101 \\
\hline & & 2019 & 94,2 & 182 \\
\hline & & 2020 & 103,7 & 838 \\
\hline \multirow[t]{5}{*}{11} & MAPI & 2016 & 6,51 & 233 \\
\hline & Mitra Adiperkasa,Tbk & 2017 & 8,25 & 169 \\
\hline & & 2018 & 10,21 & 116 \\
\hline & & 2019 & 12,1 & 85 \\
\hline & & 2020 & $-12,6$ & 189 \\
\hline \multirow[t]{5}{*}{12} & MIDI & 2016 & 21,9 & 376 \\
\hline & Midi Utama Indonesia,Tbk & 2017 & 13,35 & 429 \\
\hline & & 2018 & 8,34 & 428 \\
\hline & & 2019 & 16,1 & 317 \\
\hline & & 2020 & 14,1 & 338 \\
\hline \multirow[t]{5}{*}{13} & MKNT & 2016 & 1,72 & 18 \\
\hline & Mitra Komunikasi Nusantara,Tbk & 2017 & 13,47 & 244 \\
\hline & & 2018 & 13,57 & 231 \\
\hline & & 2019 & $-79,8$ & 529 \\
\hline & & 2020 & $-59,5$ & 630 \\
\hline \multirow[t]{5}{*}{14} & MPPA & 2016 & 1,58 & 176 \\
\hline & Matahari Putra Prima, Tbk & 2017 & $-105,9$ & 362 \\
\hline & & 2018 & $-20,49$ & 232 \\
\hline & & 2019 & $-40,1$ & 353 \\
\hline & & 2020 & $-223,5$ & 2240 \\
\hline \multirow[t]{2}{*}{15} & RALS & 2016 & 12,24 & 39 \\
\hline & Ramayana Lestari Sentosa,Tbk & 2017 & 11,64 & 40 \\
\hline
\end{tabular}




\begin{tabular}{|l|l|l|l|l|}
\hline & & 2018 & 14,07 & 33 \\
\hline & & 2019 & 19,8 & 29 \\
\hline & & 2020 & $-3,4$ & 28 \\
\hline 16 & RANC & 2016 & 9,17 & 67 \\
\hline & Supra Boga Lestari,Tbk & 2017 & 8,18 & 75 \\
\hline & & 2018 & 6,62 & 66 \\
\hline & & 2019 & 9,14 & 67 \\
\hline 17 & SONA & 2020 & 16 & 128 \\
\hline & Sona Topas Tourism Industry,Tbk. & 2017 & 8,49 & 79 \\
\hline & & 2018 & 10,96 & 90 \\
\hline & & 2019 & 8,09 & 41 \\
\hline & & 2020 & $-18,9$ & 32 \\
\hline 18 & TRIO & 2016 & 7,42 & -106 \\
\hline & Trikomsel Oke,Tbk & 2017 & 5,32 & -107 \\
\hline & & 2018 & 0,4 & -106 \\
\hline & & 2019 & 0 & -107 \\
\hline & & 2020 & 0 & -103 \\
\hline
\end{tabular}

Source: https://www.idx.co.id/

Table 2. Average Capital Structure of Companies in the Retail Trade Sub-sector on the IDX Period 2016-2020 (\%)

\begin{tabular}{|l|l|l|}
\hline Year & Capital Structure $(\%)$ & Increase/Decrease $(\%)$ \\
\hline 2016 & 120,4 & 0 \\
\hline 2017 & 154,8 & 34,3 \\
\hline 2018 & 153,2 & $-1,6$ \\
\hline 2019 & 164,0 & 10,8 \\
\hline 2020 & 328,8 & 164,8 \\
\hline
\end{tabular}

Source: www.idx.co.id

Based on Table 2, the capital structure in the retail trade sub-sector have an average decline in 2018 of $-1.6 \%$ with a value of $153.2 \%$ compared to 2017 . In 2016-2020, there was an increase capital structure of value $120.4 \%$ (2016), $154.8 \%$ (2017), and $164 \%$ (2019). This shows that the capital structure used of corporate debt are quite high. It amounted to $328.8 \%$ (2020) that indicates higher use of debt for company performance and operations.

In 2020, the COVID 19 pandemic will have an impact on the company. Bank Indonesia (BI) reported that retail sales in December 2020 had slightly improved compared to the previous month. However, if we look at it on an annual basis (year-on-year / yoy), retail sales fallen. On a monthly basis, most of the commodity groups saw an increase in retail sales. This is due to increased demand of Christmas and New Year.. This reflected on the Real Sales Index (IPR) for December 2020, which grew by $4.8 \%$ (month-to-month / $\mathrm{mt}$ ), an increase in $-1.2 \%$ (mtm in the previous month. The highest increase was due to the support of other household equipment groups and information and communication equipment. However, the increase in demand in December 2020 was not as high as the same period the previous year. This led to a 
decline in retail sales performance in December 2020 with an IPR growth of -19.2 percent (yoy), dropping more than the previous month (16.3\%) (https://www.cnbcindonesia.com/market/20210209161659-17-222216/penjualan-ritel-anjlokapa-kabar-jualannya-emiten-konsumer/1).

The main problem are indicating, there are eight companies in the retail sub sector. The profitability variable has related positively to the capital structure. Profitability should have in use of debt for company operations. Do profitability negatively affect the capital structure?

This study is going to analyzing the contraction a retail sub-sector business' performance by examining the effect of profitability as measured by ROE on capital structure as measured by DER in retail trading sub-sector companies at IDX.

\section{Literature Review}

The profitability affected capital structure (Chen, Xu, \& Yang, 2021; Liu \& Wang, 2021; Outram, Couperthwaite, Martens, \& Millar, 2021). This capital structure is very important. It has related to financial position (Sony \& Bhaduri, 2021). In this case, company managers must understand what factors affect the capital structure. Therefore, that, companies can manage financial functions and improve investor welfare. The optimal balance of risk - return (Brigham \& Houston, 2011).

Capital Structure, this capital structure is very important. It has related to financial position. In this case, company managers must understand what factors affect the capital structure. Therefore, companies can manage financial functions and improve investor welfare. In this study, it shows a company uses funding that obtained through debt, compared to funding obtained through its own capital (Fitrianingsih, Salam, \& Aeni, 2021).

The DER formula (Sony \& Bhaduri, 2021) stated by:

$$
\text { Debt to Equity Ratio }=\frac{\text { Total Liabilities }}{\text { Equity }}
$$

Profitability Ratio, this study uses ROE variable as a variable to measure profitability. ROE is a ratio that shows the extent of a level ROE (Safitri, 2020; Saha, 2021; Situm, 2021).

The ROE formula:

$$
\text { Return on Equity }=\frac{\text { Net Income }}{\text { Total Equity }}
$$

The factors that affect ROE are net income and equity. Net income often uses as a measure of performance or as a basis for other measures such as ROE or Earning per share. This net income is the difference between income and expenses. Net income is usually included in the financial statements, to be precise on the income statement. The calculation of this net profit is usually carrying out by companies' profit before tax, profit before interest and tax, or profit before interest, taxes, and depreciation. Companies can calculate net income at the end of the year by subtracting all operating costs of gross profit. Net income is the value net has used a various financial ratio formulations such as the ratio of earnings per share, net profit margin, 
and others (Melani, 2021; Safitri, 2020; Sidik, 2020).

Equity is the total capital that can describe the owner's rights over the company's assets. In a financial statement, we can find equity in the Balance-Sheet section. This equity is the difference between existing assets and liabilities, but equity cannot be sale or does not have a measure selling value may decrease due to the withdrawal of personal capital or because of the sharing of profits and losses. The types of equity in the financial statements are paid-in capital, undivided profit, revalued capital, contributed capital, and other capital. While, ROE is one of the profitability ratios that is often uses of analyzing company performance for investors. The profit in question is net income. Meanwhile, the equity (capital) that means it represented, namely difference between a company's assets and debt. Thus, ROE has defined as an indicator measuring the effectiveness of management in managing capital to generate profits. The ROE measurement scale is the same as ROA, which is in the form of a percentage (Owusu \& Alhassan, 2021; Pennacchi \& Santos, 2021; Uly, 2020).

The capital structure related stock, where the elements make up the stock price performance. The capital structure are one of the elements that determines the company's performance, in which influenced. The important basis of consideration in determining the composition of capitals. Several factors influenced capital structure decision making, one of which is profitability (Chadha \& Seth, 2021; Jiang, Shen, Lee, \& Chen, 2021). This study uses the ROE variable as a variable to measure profitability.

\section{Methodology}

\subsection{Research Framework}

A high rate of ROE using internal sources. This is better for the company to do than to use more debt. It will affect the company. (Melani, 2021; Sidik, 2020)

H1: Profitability has a negative effect on capital structure

The research site is the retail trade of a sub-sector company in IDX that has conducted starting April 2021. It derived from financial data onto the IDX website.

\section{- Research Methods and Design}

This type of research uses verification research with explanatory research methods used to test hypotheses and explain phenomena in the form of relationships between variables. Research designed is a procedure that researchers use when selecting, collecting, and analyzing data as a whole. The study has conducted with the aim at examining corporate retail trade of IDX during the 2016-2020 period. Thus, the relationship variable in this study has causally related to the unit analysis. The structural measurement of each variable uses a ratio to measure the scale.

- Samples

Researchers used purposive-sampling with research considerations. So that, future data collection is more representative (O'Halloran, Littlewood, Richardson, Tod, \& Nesti, 2018). The considerations for selecting the research sample are: 


\section{Macrothink}

1. Sample retail trade sub-sector companies listed on the IDX

2. Sample of IPO companies before 2016

3. The sample period studied was from 2016-2020

4. The sample companies did not delist from IDX during the study

5. The sample companies have complete financial data onto 2016-2020

Based on these criteria according to the sampling method used, there are 18 sample companies to employ (Knotters \& Brus, 2013):

- Research variable:

- Independent Variable (X): Profitability (ROE)

- Dependent variable (Y): Capital structure (DER)

- Data analysis technique

Using panel data regression to determine the relationship between profitability and the capital structure of the retail traded sub-sector on the IDX during the 2016-2020 period. Data processing using EViews 9 software (A Kadim \& Nardi, 2018; Sari, Silaban, Ruslan, \& Suharianto, 2021). The goal is significance dependent by using panel data, namely a combination of time series data and cross data. While, testing hypothesis using a panel-data regression-model.

In addition, there are three methods of estimating the regression model using panel data, namely: common effect model, fixed effect model, and random effect model. It based on data characteristics, namely the chow test, the Hausman test, and the Lagrange multiplier test (Ahn \& Moon, 2014; Aït-Sahalia \& Xiu, 2019). The regression model:

$$
\text { Capital Structure }_{i t}=\alpha+\beta_{1} \text { Profitability }_{\text {it }}+\varepsilon_{\text {it }}
$$

Information:

Capital structure measured by DER

Profitability measured by ROE

$\alpha=$ Constant

$\beta=$ the regression coefficient of each independent variable

$\varepsilon=$ Error terms

$t=$ Period of the year

$\mathrm{i}=$ Company crossed section

- Panel Data Regression Hypothesis Test

Hypothesis is using coefficient of determination (Adjusted $\mathrm{R}^{2}$ ), $\mathrm{F}$ and $\mathrm{T}$ test with each 
probability less than 0.05 (Liu \& Wang, 2021; Outram et al., 2021).

Keep in mind that calculating net income should be calculating in one year. However, since financial statements are usually issuing quarterly (4 months), the value must be make into one year first. There are only one quarterly available reports and even four times. While, two available reports, the value must be multiplied by two (2) and so on. It figured up on the previous explanation, the ROE of a company is $>0.694$. This indicates that the company is effective enough to generate income. This figure is close to one. Give a company has an ROE close to zero. It can be say that the company is not effective or successful in earning revenue. Every shareholder expects a high ROE considering this ratio has a high level of risk as well. $\mathrm{ROE}$ is able to compare to one period and another. In addition, the shareholders themselves need to analyze the market in order to find companies that can process better and rational ROE numbers.

\section{Result and Discussion}

The results of the tabulation this study indicated the results of the variable test in this study (Table 3):

Table 3. Test result

\begin{tabular}{|c|c|c|c|c|}
\hline \multicolumn{5}{|c|}{ Dependent Variable: DER (Capital Structure) } \\
\hline \multicolumn{5}{|c|}{ Method: Panel Least Squares } \\
\hline \multicolumn{5}{|c|}{ Date: 04/12/21 Time: $13: 30$} \\
\hline \multicolumn{5}{|l|}{ Sample: 20162020} \\
\hline \multicolumn{5}{|l|}{ Periods included: 5} \\
\hline \multicolumn{5}{|c|}{ Cross-sections included: 18} \\
\hline \multicolumn{5}{|c|}{ Total panel (balanced) observations: 90} \\
\hline Variable & Coefficient & Std. Error & t-Statistic & Prob. \\
\hline $\mathrm{C}$ & 208.0549 & 15.76352 & 13.19850 & 0.0000 \\
\hline \multirow[t]{2}{*}{ ROE (Profitability) } & -7.080276 & 0.681338 & -10.39173 & 0.0000 \\
\hline & Effects Spec & fication & & \\
\hline \multicolumn{5}{|c|}{ Cross-section fixed (dummy variables) } \\
\hline R-squared & 0.798517 & \multicolumn{2}{|c|}{ Mean dependent var } & 184.2444 \\
\hline Adjusted R-squared & 0.747436 & \multicolumn{2}{|c|}{ S.D. dependent var } & 294.4097 \\
\hline S.E. of regression & 147.9577 & \multicolumn{2}{|c|}{ Akaike info criterion } & 13.01682 \\
\hline Sum squared resid & 1554295. & \multicolumn{2}{|c|}{ Schwarz criterion } & 13.54456 \\
\hline Log likelihood & -566.7570 & \multicolumn{2}{|c|}{ Hannan-Quinn criter. } & 13.22964 \\
\hline F-statistic & 15.63258 & \multicolumn{2}{|c|}{ Durbin-Watson stat } & 1.798718 \\
\hline Prob(F-statistic) & 0.000000 & & & \\
\hline
\end{tabular}

Source: Eviews test results

Table 4.

\begin{tabular}{|l|l|l|}
\hline & ROE & DER \\
\hline Mean & 3.362922 & 184.2444 \\
\hline Median & 6.115000 & 109.0000 \\
\hline Maximum & 108.8600 & 2240.000 \\
\hline Minimum & -223.5000 & -111.0000 \\
\hline Std. Dev. & 37.61002 & 294.4097 \\
\hline
\end{tabular}




\begin{tabular}{|l|c|c|}
\hline Skewness & -2.231051 & 4.067222 \\
\hline Kurtosis & 18.25748 & 27.77435 \\
\hline Jarque-Bera & 947.6292 & 2549.767 \\
\hline Probability & 0.000000 & 0.000000 \\
\hline Sum & 302.6630 & 16582.00 \\
\hline Sum Sq. Dev. & 125891.7 & 7714261. \\
\hline Observations & 90 & 90 \\
\hline
\end{tabular}

Based on the two tables (Tables 3 and 4), the panel-data regression in this study is a fixed effect model. While, an equation model is as follows:

$$
\text { Capital Structure }_{i t}=(208,0549) \quad-(7,080276) \text { Profitability }_{i t}+\varepsilon_{i t}
$$

These results can be explaining as follows:

a) Capital Structure (DER)

b) 208.0549 is the value of the coefficient $\alpha$ (constant)

c) -7.080276 are the value of the profitability regression coefficient of ROE

d) $\varepsilon=$ Error terms

e) $\mathrm{t}=$ Period of the year (2016-2020 or 5 years)

f) $\mathrm{i}=$ Company cross-section

\section{- Hypothesis Test Results}

- Determination Coefficient Test (Adjusted $\mathrm{R}^{2}$ )

The coefficient of determination $\left(\mathrm{R}^{2}\right)$ describes the variation on the dependent variable. $\mathrm{R}^{2}$ values (Gouda \& El-Hoshy, 2020; Jain et al., 2021) indicated the limitations of the dependent variable (Liu \& Wang, 2021; Outram et al., 2021). The value $\sim$ one $\rightarrow$ independent variables provide all information on the dependent variable prediction (Liu \& Wang, 2021; Taylor et al., 2021).

Table 5. Adjusted R squared

\begin{tabular}{|l|l|l|l|}
\hline R-squared & 0.798517 & Mean dependent var & 184.2444 \\
\hline Adjusted R-squared & 0.747436 & S.D. dependent var & 294.4097 \\
\hline
\end{tabular}

Table 5 indicated, it knows that the Adjusted $\mathrm{R}^{2}$ value has a value of 0.747436 . This means that it provided predictions of variations in the dependent variable (it is close to one (1). In this case, the capital structure have influenced by profitability of $74.7436 \%$. The rest has influenced by $25.2564 \%$.

- $\quad F$ test

The $\mathrm{F}$ tested is used to determine the independent variables $(\mathrm{X} 1, \mathrm{X} 2 \ldots \mathrm{Xn})$ together had a significant effect on the dependent variable (Y). According to (Liu \& Wang, 2021; Taylor et 
al., 2021), the $\mathrm{F}$ test here aims to determine that the independent variables jointly affect the dependent variable (Outram et al., 2021).

The hypothesis testing is carried-out (Balsalobre-Lorente, Driha, Bekun, \& Adedoyin, 2020; Canchy, Girardeau, Durand, Vouillac-Mendoza, \& Ahmed, 2021) in the following steps:

$\mathrm{H}_{0}: \mathrm{b} 1, \mathrm{~b} 2, \ldots=0$ (simultaneously does not affect the independent variable $(\mathrm{X} 1, \mathrm{X} 2, \ldots)$ on the dependent variable $(\mathrm{Y})$

Ha: at least One $\mathrm{Bi}=0$ (simultaneously affects the independent variable $(\mathrm{X} 1, \mathrm{X} 2, \ldots)$ on the dependent variable $(\mathrm{Y})$

The formulation of the hypothesis (Ongan, Isik, \& Ozdemir, 2020; Pata \& Caglar, 2021) is as follows:

$\mathrm{H}_{0}$ : The independent variable (X) simultaneously has no effect on the dependent variable.

$\mathrm{Ha}$ : The independent variable (X) simultaneously affects the dependent variable.

The basis of decision making for the F test can be seeing based on the EViews table and output, namely:

Based on the calculated $\mathrm{F}$ value and $\mathrm{F}$ table:

- Give the value of $\mathrm{F}$ count $>\mathrm{F}$ table, the independent variable $(\mathrm{X})$ affects the dependent variable (Y).

- The value of $\mathrm{F}$ counted $<\mathrm{F}$ table, the independent variable $(\mathrm{X})$ had not effected on the dependent variable (Y).

The significance value of the EViews output:

- If the value is Sig. $<0.05$, the independent variable $(\mathrm{X})$ has a significant effect on the dependent variable (Y).

- The value is Sig. $>0.05$, the independent variable $(\mathrm{X})$ has no significant effect on the dependent variable $(\mathrm{Y})$.

Table 6. F test

\begin{tabular}{|c|c|c|c|}
\hline F-sta & 15.63258 & Durbin-Watson stat & 1.798718 \\
\hline Prob(F-statistic) & 0.000000 & & \\
\hline
\end{tabular}

Table 6, it knew that the probability F statistical significance valued is 0.0000 . This means that profitability has a significant effect on capital structure of a probability of $<0.05$.

- $\quad$ T tests

T tests to explain the influence of independent variables individually (Liu \& Wang, 2021; Outram et al., 2021; Taylor et al., 2021). This test has done:

$\mathrm{H}_{0}: \mathrm{b} 1=0$

Ha: $\mathrm{b} 1 \neq 0$ 
The hypothesis formula used is as follows:

$\mathrm{H}_{0}$ : The independent variable has no significant effect on the dependent variable.

Ha: The independent variable has a significant effect on the dependent variable.

The basis of T-test decision making can be seeing based on the EViews table and output, namely:

Based on the value of $t$ count and t table:

- If the value of $t$ count $>t$ table, the independent variable $(\mathrm{X})$ affects the dependent variable (Y).

- The value of $t$ count $<\mathrm{t}$ table, the independent variable $(\mathrm{X})$ has no effect on the dependent variable (Y).

Based on the significance value of the EViews output:

- If the value is Sig. $<0.05$, the independent variable $(\mathrm{X})$ has a significant effect on the dependent variable $(\mathrm{Y})$.

- If the value is Sig. $>0.05$, the independent variable $(\mathrm{X})$ has no significant effect on the dependent variable $(\mathrm{Y})$.

Testing the Effect of Profitability on Capital Structure

Table 7. $\mathrm{T}$ tests

\begin{tabular}{|l|}
\hline Dependent Variable: DER (Capital Structure) \\
\hline Method: Panel Least Squares \\
\hline Date: 04/12/21 Time: $13: 30$ \\
\hline Sample: 20162020 \\
\hline Periods included: 5 \\
\hline Cross-sections included: 18 \\
\hline Total panel (balanced) observations: 90 \\
\hline
\end{tabular}

\begin{tabular}{|l|l|l|l|l|}
\hline Variable & Coefficient & Std. Error & t-Statistic & Prob. \\
\hline$\alpha$ & 208.0549 & 15.76352 & 13.19850 & 0.0000 \\
\hline ROE (Profitability) & -7.080276 & 0.681338 & -10.39173 & 0.0000 \\
\hline
\end{tabular}

The initial hypothesis states that profitability has a negative effect on capital structure. Based on the results of the hypothesis test of Table 1, it knows that the probability of the profitability variable is 0.0000 with a negative coefficient that indicates that the variable has a significant effect on the capital structure, and the hypothesis has proven (Reject $\left.\mathrm{H}_{0}\right)$.

As one of the determining indicators of profitability, the value of ROE is one of the considerations in fundamental analysis conducted by investors. By knowing the ROE ratio, as investors, they can predict profit that they can get. Then, what is the percentage of ROE of the company that shares are worth buying?

The ROE value of a company will change from year after year. One year's ROE information 
cannot show the company's overall performance and its future performance. For companies that had debt, especially those whose value are greater than their own capital, ROE cannot be using as an accurate reference. We can use ROCE (Return on Capital Employed). Apart from ROE, Price to Book Value (PBV) must be considering, as well as its value also affects company profits. (Owusu \& Alhassan, 2021; Uly, 2020)

ROE is one of the profitability ratios that has often used in analyzing company performance for investors. The profit in question is net income. Meanwhile, equity (capital) had been seeing in the company's financial statements, namely the difference between the company's assets and liabilities. Thus, ROE defined as an indicator measuring the effectiveness of management in managing capital to generate profits. The ROE measurement scale is the same as ROA, which is in the form of a percentage (Situm, 2021).

A company will be say to be an unhealthy company not only from the quality of its human resources or from the value of its sales. However, it can be measuring from an internal financial perspective. One way to do this is by measuring the debt-to-equity ratio or the term DER (Wulandari \& Nurasik, 2015). Debt is an obligation that must be pay by the company in cash to the creditor within a certain period. It viewed from the period of repayment. The debt has divided into current, long-term and other liabilities.

Meanwhile, equity here is the right to own the company over the company's assets or assets that are net assets. This equity consists of deposits from the owners of the company and the remaining retained earnings. Current liabilities are short-term liabilities. Usually this current debt is company debt related to short-term company operations.

Long-term liabilities are a type of debt that is dangerous for a company and tends to be detrimental to the company. This long-term debt usually has a larger nominal value and has interest. Current liabilities are greater than long liabilities. This is a natural thing. Regarding DER (Yanto, Christy, \& Cakranegara, 2021), the government has issued a provision of the amount of DER that through the Minister of Finance Regulation No.169 / PMK.010 / 2015.

The provisions for the ratio of debt and equity (DER) apply to corporate taxpayers who are established has equity had calculated for the concerned. The highest ratio of debt to equity is 4: 1. There are DER exemptions from several groups of taxpayers, including banks, financial institutions, insurance and reinsurance, mining and all of their income is subject to final income tax and taxpayers who run a business in the infrastructure sector (Chen et al., 2021).

These borrowing costs include loan interest, discounts and premiums as well as additional costs related to loans, finance charges in finance leases - compensation for debt repayment guarantees loans. Even this taxpayer has an equity balance of zero (less than zero), no borrowed costs can be taking into account in the calculation of taxable income. This provision has been starting effectively from the 2016 fiscal year. Further implementation provisions, shall be regulated by the Directorate General of Taxes regulation.

\section{Conclusions}

Based on the results of the study, it well knew as the profitability measured by ROE. It has a 
negative and significant effect on the capital structure measured by DER. This shows that the retail sub-sector company is able to benefit from the company's operations. The results of these profits can be using for operations and the addition of capital without using much debt. So that, the company avoided bankruptcy.

The ability of this retail sub-sector company that can produce profits and not many used debts for company operations, investors can invest in this company in the hope of getting dividends from investment in the company.

A research results, the profitability variable has a negative-effect on ROE. This means that the company must manage its debt. So that, it does not affect the company's profitability improvement efforts by utilizing many internal sources. While, the company's funding uses a lot of debt, the return will be low. Based on descriptive statistics, companies with the best profitability and capital structure and feasible for investment are LPPF (Matahari Department Store), ACES (Ace Hardware Indonesia), and MIDI (Midi Utama Indonesia).

Nevertheless, it is not a good indicator for financial companies. As previously mentioned, the DER is closely relating to company expenses and equity, so the calculation of DER is highly dependent on financial reports (Nukala \& Rao, 2021).

According to Balance Theory, the optimal capital structure is determined by adding debt. It has benefits and costs balancing with benefits and costs. Debt benefits the company. It interested payments had calculated as expenses. While, they reduce taxable income. So that, the amount of tax paid by the company will be reduced. In addition, companies prefer to make loans or debts. They are not permanent, as well as their procurement costs are cheaper than issuing shares as additional capital. However, debt also has a negative side, namely increasing company bankruptcy.

\section{Managerial Implications}

A managerial implication is as follows:

- For the company

Based on the research results, the companies must be careful about using corporate debt for capital and company operations to avoid company bankruptcy. While, it is still able to get the results as profits. It can be using for operations and increasing company capital without using much debt. Therefore, that, the company avoid bankruptcy.

- For the Investors

Seeing the profitability of the retail sub-sector company, shows that it is able generating profit margin. It has increased the company's capital from profit rather than debt. So that, the company is able to survive. Therefore, investors can invest in this company and get dividends from the company.

\section{References}

Ahn, S. C., \& Moon, H. R. (2014). Large-N and Large-T Properties of Panel Data Estimators 
and the Hausman Test. In R. Sickles \& W. Horrace (Eds.), Festschrift in Honor of Peter Schmidt (pp. 219-258). Springer New York. https://doi.org/10.1007/978-1-4899-8008-3_7

Aït-Sahalia, Y., \& Xiu, D. (2019). A Hausman test for the presence of market microstructure noise in high frequency data. Journal of Econometrics, 211(1), 176-205.

https://doi.org/10.1016/j.jeconom.2018.12.013

Balsalobre-Lorente, D., Driha, O. M., Bekun, F. V., \& Adedoyin, F. F. (2020). The asymmetric impact of air transport on economic growth in Spain: fresh evidence from the tourism-led growth hypothesis. Current Issues in Tourism.

https://doi.org/10.1080/13683500.2020.1720624

Canchy, L., Girardeau, P., Durand, A., Vouillac-Mendoza, C., \& Ahmed, S. H. (2021). Pharmacokinetics trumps pharmacodynamics during cocaine choice: a reconciliation with the dopamine hypothesis of addiction. Neuropsychopharmacology, 46(2), 288-296.

https://doi.org/10.1038/s41386-020-0786-9

Chadha, S., \& Seth, H. (2021). Ownership structure and capital structure: A panel data study. International Journal of Business Innovation and Research, 24(3), 385-396.

https://doi.org/10.1504/IJBIR.2021.113515

Chen, H., Xu, Y., \& Yang, J. (2021). Systematic risk, debt maturity, and the term structure of credit spreads. Journal of Financial Economics, 139(3), 770-799.

https://doi.org/10.1016/j.jfineco.2020.09.002

Fitrianingsih, Salam, A., \& Aeni, H. (2021). Pengaruh current ratio, debt to equity ratio dan return on equity terhadap return saham pada perusahaan property dan real estate yang terdaftar di bursa efek indonesia. Journal of economics Business and Accounting, 4(2), 547-556. [Online] Available: www.idx.co.id

Gouda, O. E., \& El-Hoshy, S. H. (2020). Diagnostic technique for analysing the internal faults within power transformers based on sweep frequency response using adjusted r-square methodology. IET Science, Measurement and Technology, 14(10), 1057-4068.

https://doi.org/10.1049/iet-smt.2020.0048

Jain, H., Kapoor, A., Sengar, M., Chanana, R., Menon, H., Sridhar, E., ... Gujral, S. (2021). Outcomes of Patients with Primary Mediastinal B-Cell Lymphoma Treated with Dose Adjusted R-EPOCH Regimen: A Single Centre Experience. Indian Journal of Hematology and Blood Transfusion, 1-7. https://doi.org/10.1007/s12288-020-01372-y

Jiang, X., Shen, J. H., Lee, C. C., \& Chen, C. (2021). Supply-side structural reform and dynamic capital structure adjustment: Evidence from Chinese-listed firms. Pacific Basin Finance Journal, 65, 101482. https://doi.org/10.1016/j.pacfin.2020.101482

Kadim, K., \& Nardi, S. (2018). Eviews Analysis; Determinan Tourism, Restaurant and HotelCompany's Soundness and Performance. [Online] Available:

http://www.repository.upi-yai.ac.id

Knotters, M., \& Brus, D. J. (2013). Purposive versus random sampling for map validation: a 
case study on ecotope maps of floodplains in the Netherlands. Ecohydrology, 6(3), 425-434. https://doi.org/10.1002/eco.1289

Kurniawan, A. (2021). Analysis of the effect of return on asset, debt to equity ratio, and total asset turnover on share return. Journal of industrial engineering \& management research, 2(1), 2722-8878. https://doi.org/10.7777/jiemar

Liu, Q., \& Wang, L. (2021). t-Test and ANOVA for data with ceiling and/or floor effects. Behavior Research Methods, 53(1), 264-277. https://doi.org/10.3758/s13428-020-01407-2

Melani, A. (2021). The Resurrection of Retail Investors Continues in 2021, Daily Shares Transactions Translucent IDR 20 Trillion. [Online] Available:

https://www.liputan6.com/saham/read/4481109/kebangkitan-investor-ritel-berlanjut-pada-202 1-transaksi-harian-saham-tembus-rp-20-triliun

Nukala, V. B., \& Rao, S. S. (2021). Role of debt-to-equity ratio in project investment valuation, assessing risk and return in capital markets. Future Business Journal, 7(1), 1-23. https://doi.org/10.1186/s43093-021-00058-9

O’Halloran, L., Littlewood, M., Richardson, D., Tod, D., \& Nesti, M. (2018). Doing descriptive phenomenological data collection in sport psychology research. Sport in Society, 21(2), 302-313. https://doi.org/10.1080/17430437.2016.1159199

Ongan, S., Isik, C., \& Ozdemir, D. (2020). Economic growth and environmental degradation: evidence from the US case environmental Kuznets curve hypothesis with application of decomposition. Journal of Environmental Economics and Policy, 1-8.

https://doi.org/10.1080/21606544.2020.1756419

Outram, J. G., Couperthwaite, S. J., Martens, W., \& Millar, G. J. (2021). Application of non-linear regression analysis and statistical testing to equilibrium isotherms: Building an Excel template and interpretation. Separation and Purification Technology, 258, 118005. https://doi.org/10.1016/j.seppur.2020.118005

Owusu, F. B., \& Alhassan, A. L. (2021). $<$ scp $>$ Asset-Liability $</$ scp $>$ Management and bank profitability: Statistical cost accounting analysis from an emerging market. International Journal of Finance \& Economics, 26(1), 1488-1502. https://doi.org/10.1002/ijfe.1860

Pata, U. K., \& Caglar, A. E. (2021). Investigating the EKC hypothesis with renewable energy consumption, human capital, globalization and trade openness for China: Evidence from augmented ARDL approach with a structural break. Energy, 216, 119220.

https://doi.org/10.1016/j.energy.2020.119220

Pennacchi, G. G., \& Santos, J. A. C. (2021). Why do banks target ROE? Journal of Financial Stability, 54, 100856. https://doi.org/10.1016/j.jfs.2021.100856

Safitri, K. (2020). Closed 2020 Stock Trading, Retail Investors Support Capital Market Stability. [Online] Available:

https://money.kompas.com/read/2020/12/30/184000526/perdagangan-saham-2020-ditutup-in vestor-retail-jadi-penopang-stabilitas-pasar 


\section{Macrothink}

Business and Economic Research ISSN 2162-4860 2021, Vol. 11, No. 3

Saha, A. (2021). The use of return on equity as a criterion for stock selection in the Indian equity markets. Journal of Physics: Conference Series, 1784, 12012.

https://doi.org/10.1088/1742-6596/1784/1/012012

Sari, P., Silaban, M. J., Ruslan, D., \& Suharianto, J. (2021). An Attempt to Improve the EViews-Based Econometrics Learning. Atlantis Press.

https://doi.org/10.2991/AEBMR.K.210220.042

Sidik, S. (2020). Retail Investors: Rulers \& Shock Breakers of the Indonesian Stock Exchange During Crisis. [Online] Available:

https://www.cnbcindonesia.com/market/20201124092800-17-204111/investor-ritel-penguasashock-breaker-bursa-ri-saat-krisis

Situm, M. (2021). Determination of expected cost of equity with the CAPM: Theoretical extension using the law of error propagation. Managerial and Decision Economics, 42(1), 77-84. https://doi.org/10.1002/mde.3214

Sony, B., \& Bhaduri, S. (2021). Information asymmetry and financing choice between debt, equity and dual issues by Indian firms. International Review of Economics and Finance, 72, 90-101. https://doi.org/10.1016/j.iref.2020.11.001

Taylor, M. D., Johnson, D. D., Nilsson, S., Lin, C. Y., Braeunig, J., Mueller, J., \& Bowles, K. C. (2021). Trial of a novel experimental design to test depuration of PFASs from the edible tissues of Giant Mud Crab following exposure under natural conditions in the wild. Science of the Total Environment, 758, 143650. https://doi.org/10.1016/j.scitotenv.2020.143650

Uly, Y. (2020, October 22). Growing Rapidly in the Middle of a Pandemic, Capital Market Retail Investors Reach 4.16 Million. [Online] Available:

https://money.kompas.com/read/2020/10/22/075100826/tumbuh-pesat-di-tengah-pandemi-inv estor-ritel-pasar-modal-capai-4-16-juta

Wulandari \& Nurasik. (2015). Analysis of The Effect of Capital Structure Variables on Financial Performance in Food and Beverage Manufacturing Companies Registered in Indonesia Stock Exchange For. Academicia Globe: Inderscience Research, 2(04), 17-28. [Online] Available: https://agir.academiascience.org/index.php/agir/article/view/48

Yanto, E., Christy, I., \& Cakranegara, P. A. (2021). The Influences of Return on Asset, Return on Equity, Net Profit Margin, Debt Equity Ratio and Current Ratio Toward Stock Price. International Journal of Science, Technology \& Management, 2(1), 300-312.

https://doi.org/10.46729/ijstm.v2i1.155

\section{Copyright Disclaimer}

Copyright for this article is retained by the author(s), with first publication rights granted to the journal.

This is an open-access article distributed under the terms and conditions of the Creative Commons Attribution license (http://creativecommons.org/licenses/by/4.0/). 